\title{
Historisitas Perkembangan Tafsir Pada Masa Kemunduran Islam: Abad Kesembilan Dan Kesepuluh Hijriah
}

\author{
Eko Zulfikar \\ Institut Agama Islam Negeri Tulungagung \\ ekozulfikar2020@gmail.com
}

\begin{abstract}
This article aims to discuss the history of the development of interpretations in the ninth and tenth centuries. Interpreters in this century no longer felt enough to just quote the history of the movement of friends, tabi'in and tabi'-tabi'in in interpreting the Qur'an, but they began to be oriented towards the interpretation of the Qur'an based on the scientific approach language and scientific reasoning. With pure literature study with a content analysis approach, this paper concludes that the interpreters in the ninth and tenth centuries have similarities in interpreting the verses of the Qur'an, namely a simple pattern by displaying the meaning of a word or equivalent word. In general, the methodology of interpretation in this century includes; (1) the source of the interpretation combines the interpretations of bi al-ma 'tsur and bi al-ra' yi; (2) how to explain using bayani; (3) the breadth of the explanation of the majority using the ijmali method; (4) the objectives and order of the verses use the tahlili method; and (5) the tendency of the flow in its interpretation to use linguistic aspects, namely lughawi.
\end{abstract}

Key Word: Historical, Developmental Interpretations, Ninth And Tenth Centuries

\begin{abstract}
Abstrak
Artikel ini bertujuan untuk membahas historisitas perkembangan tafsir pada abad kesembilan dan kesepuluh hijriyah. Para mufassir pada abad ini tidak lagi merasa cukup dengan hanya mengutip riwayat dari gerakan sahabat, tabi'in dan tabi'-tabi'in dalam menafsirkan al-Qur'an, tetapi mereka mulai berorientasi pada penafsiran al-Qur'an berdasarkan pada pendekatan ilmu bahasa dan penalaran ilmiah. Dengan murni studi pustaka dengan pendekatan
\end{abstract}


analisis isi, tulisan ini memberi kesimpulan bahwa para mufassir pada abad kesembilan dan kesepuluh memiliki kemiripan dalam menafsirkan ayat-ayat al-Qur'an, yakni pola sederhana dengan menampilkan makna kata ataupun padanan kata. Secara umum, metodologi penafsiran pada abad kesembilan dan kesepuluh antara lain; (1) sumber penafsirannya memadukan antara tafsir bi alma'tsur dan tafsir bi al-ra' yi; (2) cara penjelasannya menggunakan bayani; (3) keluasan penjelasannya mayoritas menggunakan metode ijmali; (4) sasaran dan tertib ayatnya memakai metode tahlili; dan (5) kecenderungan aliran dalam penafsirannya menggunakan aspek kebahasaan, yakni lughawi.

Kata Kunci: Historis, Perkembangan tafsir, Abad Kesembilan dan Kesepuluh

\section{Pendahuluan}

Telah menjadi lazim bahwa penafsiran al-Qur'an telah berlangsung sejak zaman Nabi Muhammad hingga sekarang, bahkan juga pada masa mendatang. Realitas sejarah membuktikan bahwa penafsiran kaum Muslim terhadap kitab sucinya (baca: tafsir) selalu berkembang seiring dengan perkembangan peradaban dan budaya manusia. Hal ini karena seorang penafsir senantiasa berupaya untuk memikirkan dan menemukan makna dan pesan yang belum bisa dipahami dari teks ayat-ayat al-Qur'an. Namun kemampuan seorang penafsir ini hanya bisa sampai pada derajat pemahaman relatif dan tidak bisa mencapai derajat absolut. ${ }^{1}$

Historisitas tafsir al-Qur'an sejatinya dimulai dengan menafsirkan ayat-ayat al-Qur'an berdasarkan hadis Nabi, pendapat sahabat dan tabi'in. Penafsiran semacam ini berkembang dengan pesat, sehingga disadari ataupun tidak, hadis shahih bercampur dengan israiliyyat. Di samping itu, pesan Tuhan yang terekam dalam al-Qur'an ternyata juga tidak dipahami sama dari waktu ke waktu, ia senantiasa dipahami selaras dengan realitas dan kondisi yang berjalan seiring dengan tuntutan zaman. Dengan kata lain, kitab suci al-Qur'an dipahami secara beragam, selaras dengan kebutuhan umat Islam sebagai konsumennya.

Secara global, sebagian ahli tafsir membagi periodesasi penafsiran alQur'an ke dalam tiga fase; periode mutaqaddimin (abad 1-4 H), periode

${ }^{1}$ Eko Zulfikar, Makna Ulu al-Albab Dalam al-Qur'an: Analisis Semantik Toshihiko Izutsu, dalam Jurnal Theologia, Vol 29, No 1, Juni 2018, 110. 
mutaakhirin (abad 4-12 H), dan periode baru (abad 12-sekarang). Menurut alDzahabi, periodesasi tafsir al-Qur'an dapat dibedakan menjadi tiga tahap; (1) tafsir al-Qur'an pada masa Nabi dan sahabatnya; (2) tafsir pada masa tabi'in, dan (3) tafsir pada masa kodifikasi (pembukuan al-Qur'an). Selain itu, ada juga ulama yang membagi periodesasi tafsir menjadi tiga periode: (1) periode klasik, (2) periode pertenghan yang mencakup masa keemasan dan sekaligus kemunduran umat Islam, dan (3) periode kontemporer. ${ }^{2}$ Segmentasi ini dilakukan berdasarkan kenyataan bahwa tafsir al-Qur'an pada zaman Nabi memiliki perbedaan yang signifikan dengan tafsir al-Qur'an pada masa sahabat, lebih-lebih pada masa generasi Muslim berikutnya.

Tulisan ini secara spesifik membahas perkembangan tafsir al-Qur'an pada abad kesembilan dan kesepuluh. Selain alasan karena tafsir al-Qur'an pada abad ini termasuk pada fase mutaakhirin atau lazim disebut dengan fase pertengahan, juga karena pada abad ini, umat Islam sedang mengalami puncak kemunduran dalam bidang ilmu pengetahuan. Dengan demikian, untuk mendapatkan pemahaman yang komprehensif, penulis menggunakan studi kepustakaan (library research) yang menitikberatkan pada beberapa literatur referensi relevan dengan tema yang dibahas. Selain itu, mengingat tulisan ini murni studi pustaka, maka semua sumber datanya adalah dokumentasi dengan pendekatan analisis isi (content analysis), yakni menganalisa suatu permasalahan dengan menarik kesimpulan yang replikatif dan benar dari data atas dasar konteksnya.

\section{Pembahasan}

\section{Faktor-Faktor Penyebab Kemunduran Islam}

Kemunduran Islam pada abad ini tidak dapat dikaitkan dengan satu atau dua faktor semata. Karena penyebab jatuhnya Islam ini secara tidak langsung mengacu pada beberapa pengaruh yang berasal dari dalam (internal) maupun dari luar (eksternal). Secara garis besar, beberapa faktor penyebab kemunduran Islam antara lain:

1. Pemimpin tidak mengamalkan ajaran agama

Salah satu faktor penyebab kemunduran Islam adalah karena gaya hidup para penguasanya gemar bermewah-mewahan, royal dan berorientasi pada duniawi semata. Pola hidup yang serakah, kikir, iri hati, ambisi kekuasaan

${ }^{2}$ Muhammad Husain al-Dzahabi, al-Tafsir wa al-Mufassirun, Juz I, (Kairo: Dar alHadith, 2005), 32. Lihat juga, Abdul Mustaqim, Aliran-aliran Tafsir, (Yogyakarta: Kreasi Wacana, 2005), 28-88. 
dan tidak mementingkan kehidupan rohani dan ukhrawi menjadi gaya hidup para penguasa. Mereka telah menggunakan tangan besi dalam kepemimpinan dan menganggap ajaran Islam hanya berlaku dalam kehidupan nyata. Sehingga mereka mengklaim dirinya sebagai wakil Tuhan di bumi, dan harus ditaati secara absolut dan mutlak, tidak boleh dibantah dan harus dihormati, meskipun terdapat kezaliman dan tidak adil. ${ }^{3}$

\section{Serangan tentara Mongol dan runtuhnya Abbasiyah}

Pada tahun $565 \mathrm{H} / 1258 \mathrm{M}$, tentara Mongol berjumlah 200.000 pasukan yang dipimpin oleh Hulagho Khan telah menyerang dan menghancurkan khalifah al-Mu'tashim yang berkuasa saat itu. Kota Baghdad dihancurkan secara merata dan Hulagho berkuasa selama dua tahun sebelum melanjutkan serangannya ke Syiria dan Mesir. Jatuhnya kota Baghdad ke tangan bangsa Mongol ini bukan saja mengakhiri khalifah Abbasiyah, namun juga merupakan embrio dari massa kemunduran politik dan peradaban Islam. Khalifah sebagai simbol pemersatu umat Islam di dunia mulai hilang. Sementara perpustakaan terbesar di dunia saat itu - Baitul Hikmah, yang menyimpan banyak dokumen sejarah dan buku berharga dalam berbagai disiplin ilmu juga telah hancur. ${ }^{4}$

3. Terjadi disintegrasi umat Islam

Embrio perpecahan dan disintegrasi sejatinya telah muncul di tubuh umat Islam sejak periode akhir pemerintahan Abbasiyah. Hal ini ditandai dengan adanya konflik antara Sunni dan Syi'ah yang semakin tajam. Setelah Abbasiyah hancur, eskalasi konflik semakin memuncak akibat kontradiksi pemahaman agama dalam aspek ideologis, teologis dan berujung pada konflik geografis. Umat Islam mengalami perpecahan menjadi nation-state kecil akibat kuatnya disentegrasi.

Secara umum, di masa akhir pemerintahan Abbasiyah, wilayah teritorial Islam terbagi menjadi dua; pertama, bagian Arab yang terdiri dari Arabia, Suriah, Iraq, Palestina, Mesir dan Afrika Utara dengan Mesir sebagai pusatnya. Kedua, bagian Persia yang terdiri atas Balkan, Asia kecil, Persia dan Asia Tengah dengan Iran sebagai pusatnya. Secara rill, daerah-daerah tersebut berada dibawah kekuasaan gubernur-gubernur yang bersangkutan. Relasi dengan khalifah hanya ditandai dengan pembayaran upeti, sehingga berimplikasi pada ketidak-percayaan para penguasa kepada khalifah, di 25.

${ }^{3}$ Falahudin, dkk, Kuliah Kemuhammadiyahan, (Mataram: LP2I UM. Mataram, 2015),

${ }^{4}$ Falahudin, Kuliah Kemuhammadiyahan, 27.

Tribakti: Jurnal Pemikiran Keislaman

Volume 30, Nomor 2, Juli 2019 
samping mereka lebih menitik-beratkan pembinaan peradaban dan kebudayaan daripada politik dan ekspansi. ${ }^{5}$

\section{Perang Salib}

Perang Salib adalah gerakan umat Kristen di Eropa yang memerangi umat Muslim di Palestina secara berulang-ulang. Di samping dengan tujuan untuk merebut Tanah Suci dari kekuasaan kaum Muslim dan mendirikan Gereja, juga ingin mendirikan kerajaan Latin di Timur. Dinamakan Perang Salib, karena setiap orang Eropa yang ikut bertempur dalam peperangan memakai tanda salib pada bahu, lencana dan panji-panji mereka. Perang Salib ini berpengaruh luas terhadap politik, ekonomi dan sosial, bahkan terasa masih berpengaruh sampai masa kini. Meski pada kenyataanya umat Islam berhasil memperthankan daerahnya dari tentara salib, namun kekuatan politik umat Islam menjadi lemah, sehingga terpecah belah dan ingin memerdekakan diri dari kekuasaan Islam di Abbasiyah. Dalam konteks hubungan antar-agama, Negara-negara barat sampai saat ini masih membenci Islam, karena perang salib meninggalkan trauma yang mendalam antara Islam dan Kristen. ${ }^{6}$

5. Kemerosotan Ekonomi

Dalam lintasan sejarah, khalifah Abbasiyah telah mengalami degradasi dibidang ekonomi bersamaan dengan bidang politik. Pada periode pertama, pemerintah Banni Abbas merupakan pemerintahan yang kaya. Dana yang masuk lebih besar dari yang keluar, sehingga Baitul Mal penuh dengan harta kekayaan. Pertambahan dana yang besar ini diperoleh antara lain dari alkharaja -semacam pajak hasil bumi. Namun seiring perkembanganya, kondisi politik yang tidak stabil menyebabkan perekonomian Negara mengalami degradasi. Sebaliknya, kondisi ekonomi yang buruk memperlemah kekuatan politik dinasti Abbasiyah, kedua faktor ini saling berkaitan dan tidak terpisahkan.

Secara umum, faktor kemunduran ini dikarenakan pendapatan Negara yang terus menurun dan pengeluaran meningkat lebih besar. Menurunnya pendapatan Negara disebabkan tidak berjalannya ekspansi Islam. Di samping wilayah kekuasaan semakin sempit, juga banyak terjadi kerusuhan yang mengganggu perekonomian rakyat. Selain itu, dinasti-dinasti kecil banyak yang memerdekakan diri dan tidak lagi membayar upeti. Adapun pengeluaran membengkak antara lain disebabkan oleh kehidupan para khalifah yang

${ }^{5}$ Falahudin, Kuliah Kemuhammadiyahan, 28.

${ }^{6}$ Falahudin, Kuliah Kemuhammadiyahan, 28.

Tribakti: Jurnal Pemikiran Keislaman Volume 30, Nomor 2, Juli 2019 
semakin royal dan mewah, jenis pengeluaran semakin beragam dan para pejabat sering melakukan korupsi. ${ }^{7}$

\section{Perkembangan Tafsir Pada Abad Kesembilan dan Kesepuluh}

Ekspansi Islam pada masa tabi' in dan tabi'-tabi' in yang dilakukan secara agresif dan mobilitas ke berbagai daerah semakin mengembangkan wilayah Islam. Ekspansi Islam dengan dunia luar Arab yang notabene nonMuslim pun turut mempengaruhi kompleksitas problematika yang dihadapi oleh umat Islam. Pada zaman ini, Islam telah menguasai berbagai daerah lain yang memiliki kebudayaan lama yang berhubungan erat dengan paganisme atau agama berhala seperti Persia, Asia Tengah, India, Siria, Turki, Mesir, Etiopia, dan Afrika Selatan. Bahkan Islam berkembang luas pula di wilayah Asia tenggara yang sebelumnnya dikuasai oleh keyakinan Budha dan Hindu.

Sejak saat itu, kaum Muslim mulai mempelajari ilmu Sains yang dimiliki oleh para penganut kebudayaan tersebut. Dengan adanya ekspansi Islam yang hampir menyebar di seluruh penjuru benua, peradaban dan kebudayaan Islam pun semakin meningkat pesat, termasuk ilmu tafsir. Dalam upaya menafsirkan al-Qur'an, para pakar tafsir tidak lagi merasa cukup dengan hanya mengutip atau menghafal riwayat dari gerakan sahabat, tabi'in, dan tabi'-tabi'in - seperti yang diwarisinya selama ini, tetapi mereka mulai berorientasi pada penafsiran al-Qur'an berdasarkan pada pendekatan ilmu bahasa dan penalaran ilmiah. Dengan kata lain, tafsir al-Qur'an pada periode ini tidak hanya mengandalkan dominasi tafsir bi al-ma'tsur yang telah berkembang di masyarakat, namun juga berupaya keras mengembangkan tasir bi al-ra'yi dengan segala macam implikasinya. ${ }^{8}$

Berbagai alasan di atas inilah yang secara umum melatarbelakangi tampilnya beberapa karakteristik dalam penafsiran al-Qur'an pada masa ini, di mana tafsir al-Qur'an mengalami perkembangan sedemikian rupa dengan penitik-beratan (fokus-perhatian) pada pembahasan aspek-aspek tertentu sesuai dengan tendensi dan kecenderungan kelompok mufassir yang ditengarai perbedaannya dengan tafsir pada periode klasik. Di antara kitab-kitab tafsir yang lahir dalam abad kesembilan dan kesepuluh ini adalah:

1. Tanwir al-Miqbas min Tafsir Ibn 'Abbas karya 'Abdullah Ibn 'Abbas, dengan editor Thahir Muhammad bin Ya'qub al-Fairuzabadi, termasuk tafsir bi al-Ma'tsur.

\footnotetext{
${ }^{7}$ Badri Yatim, Sejarah Kebudayaan Islam, (Jakarta: PT Rajawali Press, 2014), 81-82.

${ }^{8}$ Ahmad Izzan, Metodologi Ilmu Tafsir, (Bandung: Tafakur, 2009), 22-23.
} 
2. Tafsir al-Jalalain karya Jalaluddin al-Mahalli dan ditamatkan oleh Jalaluddin al-Sayuthi, termasuk tafsir bi al-ra'yi.

3. Tafsir al-Dur al-Mantsur Mukhtashar Tarjuman al-Qur'an karya Jalaluddin al-Sayuthi, termasuk tafsir bi al-Ma'tsur.

4. Tafsir al-Siraj al-Munir karangan al-Sharbani, termasuk tafsir bi al-ra' $y i^{9}{ }^{9}$

\section{Metodologi Penafsiran Abad Kesembilan dan Kesepuluh}

Dalam konteks pembahasan ini, penulis akan menyoroti tafsir Tanwir al-Miqbas min Tafsir Ibn 'Abbas dan tafsir al-Jalalain sebagai representasi dari penafsiran abad kesembilan dan kesepuluh;

\section{Tafsir Tanwir al-Miqbas min Tafsir Ibn 'Abbas}

a. Biografi 'Abdullah Ibn 'Abbas

Nama 'Abdullah Ibn 'Abbas tidak dapat ditinggalkan ketika seseorang membicarakan tafsir al-Qur'an. Di dalam dunia tafsir, Ibn 'Abbas dianggap the real father of the science of Tafsir. Laporan terkait dari Ibn 'Abbas mengenai tafsir al-Qur'an sangat melimpah. Bahkan hampir tidak ada ayat al-Qur'an yang tidak dikaitkan dengan penafsiran Ibn 'Abbas. ${ }^{10}$ Selain karena Ibn 'Abbas termasuk sahabat yang masih hidup pada zaman dimana wilayah Islam sudah meluas dan kebutuhan tafsir ayat-ayat al-Qur'an semakin meningkat, ${ }^{11}$ ia juga yang secara langsung mendapatkan doa khusus dari Nabi Saw. Dapat dinyatakan bahwa Ibn 'Abbas-lah yang mendapat legitimasi langsung dari Nabi menjadi salah seorang yang mampu memahami dan menafsirkan al-

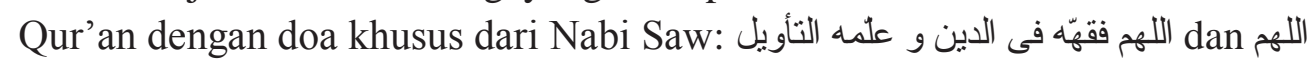
'اللهم علمه الحكمة serta آته الحكمة 'Abas

Nama lengkap Ibn 'Abbas adalah 'Abdullah Ibn 'Abbas bin 'Abdul Muthallib bin Hasyim bin 'Abdul Manaf al-Hasyimi, putra paman Nabi Saw. Ibunya bernama Lubabah al-Kubra binti al-Harits bin Hazan al-Hilaliyah, lebih dikenal dengan Umm al-Fadhl. Ibnu 'Abbas dilahirkan ketika Nabi Muhammad beserta keluarganya (Bani Muthallib) dan Bani Hasyim berada di

${ }^{9}$ Muhammad Hasbi al-Shiddiqi, Sejarah dan Pengantar Ilmu al-Qur'an dan Tafsir, (Semarang: Pustaka Rizki Putra, 2012), 200.

10 Abdullah Ibn 'Abbas Muhammad al-Fairuzabadi, Tanwir al-Miqbas min Tafsir Ibn 'Abbas, (Amman: Royal Alul Bait, 2007), iv.

${ }_{11}$ Muhammad 'Abdul 'Adzim al-Zarqani, Manahil al- 'Irfan fi 'Ulum al-Qur'an, Juz II, (Beirut: Dar al-Kutub al-'Arabi, 1995), 18.

12 Muhammad Jalaluddin al-Suyuthi, al-Itqan fi 'Ulum al-Qur'an, (Kairo: Dar alHadits, 2004), 991. 
Syi'b, Makkah, kurang lebih tiga tahun sebelum hijrah, yakni pada masa pemboikotan suku Quraisy terhadap keluarga Nabi dan yang mendukungnya (Bani Hasyim dan Bani Muthallib). ${ }^{13}$

Masa kecil Ibn 'Abbas sudah dalam keadaan Islam beserta ayah ibunya, hanya saja identitas keislamannya disembunyikan untuk menghindari perilaku destruktif suku Quraisy. Ibn 'Abbas hidup di Mekkah setidaknya sampai tahun ke-8 Hijriah, bertepatan pada saat berusia kurang lebih 11 tahun, yakni saat sebelum pembebasan kota Makkah (Fath Makkah). Di tengah perjalanan menuju hijrah ke Madinah, Ibn 'Abbas dan keluarganya bertemu dengan Nabi dan pasukannya yang hendak membebaskan kota Makkah, tepatnya di Rabigh dekat Juhfah, $187 \mathrm{~km}$ dari arah barat laut Masjid al-Haram Makkah. ${ }^{14}$

Selama di Madinah, Ibn 'Abbas selalu menghabiskan waktu bersama Nabi. Selain alasan karena ia termasuk salah satu kerabat dekat Nabi, juga dikarenakan bibinya Maimunah adalah salah seorang istri Nabi. Ibnu 'Abbas juga sering memasuki rumah Nabi dan terkadang menginap untuk berkhidmat dan menimba ilmu kepada Nabi. Setelah Nabi wafat yang bertepatan usia Ibn 'Abbas mencapai 13 tahun, ia selalu bersama sahabat senior untuk menimba ilmu dan mengejar apa yang tertinggal darinya hadis-hadis Nabi. Ibnu 'Abbas wafat dan dikuburkan di kota Thaif pada tahun $68 \mathrm{H}$, yakni berusia 71 tahun. ${ }^{15}$

Secara umum, kemasyhuran Ibn 'Abbas di bidang tafsir dan keilmuannya menjadikan ia banyak dikenal dengan beberapa julukan, antara lain: bahr al-'ilm (lautan ilmu), habr al-ummah (ulama umat), tarjuman alQur'an (juru tafsir al-Qur'an), rais al-mufassirin (pemimpin pakar tafsir), dan habr al-Qur'an (ulama al-Qur'an). Beberapa julukan di atas merupakan legitimasi atas keluasan ilmu dan pengetahuan Ibn 'Abbas terhadap makna kandungan ayat al-Qur'an, sehingga ia banyak dijadikan rujukan sahabat dalam tafsir maupun fatwa.

Ali bin Abi Thalib pernah menyebut Ibn 'Abbas sebagai orang yang sangat kuat dalam memahami ilmu. Bahkan Umar bin Khattab juga memprioritaskannya, padahal Ibn 'Abbas masih remaja sebagai sahabat yang paling prominen dan paling progresif. Hal ini sangat tampak pengaplikasian kognitif akan tingginya keistimewaan yang dimiliki Ibn 'Abbas dalam menafsirkan al-Qur'an pada kalimat yang dikutip muridnya, Mujahid. "Ketika

\footnotetext{
${ }^{13}$ Al-Dzahabi, al-Tafsir wa al-Mufassirun, 50.

${ }^{14}$ M Quraish Shihab, Membaca Sirah Nabi Muhammad Saw Dalam Sorotan al-Qur'an dan Hadits-Hadits Shahih, (Jakarta: Lentera hati, 2011), 907.

${ }^{15} \mathrm{Al}$-Dzahabi, al-Tafsir wa al-Mufassirun, 50.
} 
Ibnu 'Abbas menafsirkan ayat al-Qur'an, aku melihat seberkas cahaya di wajahnya." 16

Di antara sebab keunggulan dan kemasyhuran Ibn 'Abbas di bidang ilmu, khususnya bidang tafsir menurut sebagian ulama adalah:

1) Mendapat doa khusus dari Nabi: اللهم فقهّه فى الدين و علمه التُأويل . اللهم علمه الحكمة serta آته الحكمة.

2) Banyak waktu dihabiskan di kediaman Nabi dan istrinya Maimunah, sehingga Ibn 'Abbas banyak belajar dari Nabi dan menyaksikan berbagai peristiwa yang berkaitan dengan nuzul al-Qur'an.

3) Interaksi Ibn 'Abbas dengan sahabat senior setelah wafatnya Nabi, yang menjadikannya banyak meriwayatkan dan mengetahui dari sahabat tempat-tempat nuzul al-Qur'an, tarikh tasyri', asbab al-nuzul dan beberapa hal yang berkaitan dengan al-Qur'an.

4) Pengetahuannya yang luas terhadap sastra Arab meliputi bait syairsyair jahiliyah beserta bentuk-bentuknya, dan juga memahami katakata yang terasa aneh bagi umumnya orang Arab pada masa itu.

5) Pencapaian Ibn 'Abbas pada tingkatan mujtahid dan keberaniannya dalam menjelaskan apa yang diyakininya benar. ${ }^{17}$

Metode penafsiran Ibn 'Abbas dalam menafsirkan ayat sesuai dengan metode yang berlaku pada saat itu, yakni dengan jalur riwayat (bi al-ma'tsur). Selain itu, Ibn 'Abbas juga menggunakan syair-syair Arab kuno sebagai sarana penunjang yang membantu pemahaman makna lafadz yang gharib dari alQur'an. Ibn 'Abbas menyatakan, "Bila kalian bertanya kepadaku tentang lafadz yang gharib dalam al-Qur'an, carilah keterangannya dari syair-syair Arab kuno, karena syair Arab kuno merupakan sumber rujukan bahasa Arab (diwan al- 'Arab)." Di samping itu, Ibn 'Abbas juga merujuk kepada ahlu alkitab yang sesuai dengan kandungan dan ajaran al-Qur'an.

Selain metode di atas, Ibn 'Abbas juga menggunakan ijtihad dalam menafsirkan ayat. Ia memiliki kecenderungan untuk menggunakan akal pikiran yang jernih dalam menafsirkan ayat al-Qur'an. Ia juga tidak monoton menggunakan standar baku penafsiran ayat dengan ayat lainnya, atau ayat dengan hadis Nabi Saw. Ibn 'Abbas berani berijtihad dan diakui oleh kalangan

${ }^{16}$ Ignaz Goldziher, Madzhab Tafsir, terj. Alaika Salamullah dkk, (Jogjakarta: Elsaq Press, 2010), 89.

${ }^{17}$ Al-Dzahabi, al-Tafsir wa al-Mufassirun, 52. 
para sahabat. Sebagai contoh representatif tafsirnya adalah ketika Ibn Umar meminta Ibn 'Abbas untuk menafsirkan QS. al-Anbiya [21]: 30;

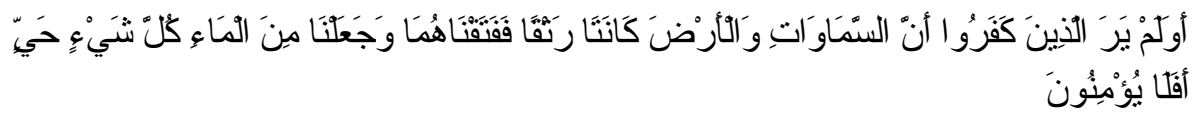

Dan apakah orang-orang yang kafir tidak mengetahui bahwasanya langit dan bumi itu keduanya dahulu adalah suatu yang padu, Kemudian kami pisahkan antara keduanya. dan dari air kami jadikan segala sesuatu yang hidup. Maka mengapakah mereka tiada juga beriman?

Dalam menafsirkan ayat ini, Ibn 'Abbas tidak merujuk kepada alQur'an maupun hadis Nabi, namun ia merujuk pada pemikirannya sendiri. Berkaitan dengan ini, Ibn 'Abbas mengatakan bahwa langit itu bersatu dengan bumi. Maksudnya adalah langit tidak menurunkan hujan, dan bumi tidak menumbuhkan tanaman. Oleh karena itu, Allah memisahkan keduanya dengan menurunkan hujan dari langit dan menumbuhkan tumbuh-tumbuhan di bumi. 18

\section{b. Biografi al-Fairuzabadi}

Nama lengkapnya adalah Muhammad bin Ya'qub bin Muhammad bin Ibrahim bin 'Umar Abu Thahir al-Syairazi al-Fairuzabadi. ${ }^{19}$ Al-Fairuzabadi dinisbatkan kepada daerah yang bernama Fairuzabad, sebuah kota di Persia dekat Syairaz, saat ini daerah tersebut menjadi bagian dari wailayah Azarbaijan. ${ }^{20}$ Al-Fairuzabadi lahir pada bulan Rabi' al-Akhir tahun 729 H di Karizin, sebuah kota di Iran antara al-Bahr dan Syairaz, dan meninggal pada tanggal 20 Syawwal tahun $818 \mathrm{H}$ di daerah Zabid. Ia tumbuh dan menghafal al-Qur'an pada usia 7 tahun saat berada di Karizin tersebut. Kemudian setelah pindah ke Syairaz, ia belajar bahasa serta adab dari ayahnya sendiri di samping kepada Qawamuddin ‘Abdullah bin Mahmud dan lainnya.

Selanjutnya al-Fairuzabadi ke Baghdad untuk belajar kepada Tajuddin Muhammad bin al-Sabbak. Kemudian ia menuju Damaskus dan Quds untuk belajar kepada lebih dari 100 guru yang membawanya kepada kemasyhuran,

\footnotetext{
${ }^{18}$ Al-Dzahabii, al-Tafsir wa al-Mufassirun, 57.

${ }^{19}$ Syamsuddin Muhammad bin 'Ali bin Ahmad al-Dawusi, Thabaqat al-Mufassirin, (Ttp: Maktabah Wahbah Abidin, 1992), 312.

${ }^{20}$ Farid 'Abdul 'Aziz al-Jundi, Mu 'jam al-Buldan, Juz IV, (Beirut: Dar al-Kutub al'Ilmiyyah, 1990), 321.
} 
karena pada saat inilah ia mulai mengembangkan intelektualnya dengan menerbitkan karya-karyanya. Setelah itu, al-Fairuzabadi ke Kairo dan belajar kepada al-Jamal al-Asnawi, Ibn Hisyam, al-Baha' bin 'Uqail dan beberapa ulama lain. Perjalanan ilmiah al-Firuzabadi ini berlangsung secara terus menerus hingga mencapai wilayah Tenggara menuju Roma, India dan beberapa kota lainnya. ${ }^{21}$

Al-Fairuzabadi bermadzhab fiqih Syafi'i, dan familiar hingga hari ini untuk karya monumentalnya al-Qamus al-Muhith. Namun kontribusinya dalam khazanah keIslaman meluas ke domain lainnya selain tata bahasa. Bahkan spesialisasi utama al-Fairuzabadi adalah hadis dan sejarah. Dia menulis lebih dari 48 buku, enam di antaranya berhubungan dengan studi alQur'an, yaitu Taisir Fatihat al-Tafsir fi Anab Fatihat al-Kitab, al-Durr alNadzim: al-Mursyid ila Maqasyid al-Qur'an al- 'Adzim, Hasil Kurat al-Khalas fi Fadhail Surat al-Ikhlas, Syarh Qutbat Kasysyaf, dan Basha'ir Dhawi alTamyiz fi Latha'if al-Kitab al- 'Aziz. ${ }^{22}$

Beberapa karyanya yang lain adalah seperti al-Qamus al-Muhit wa alQabus al-Wasith, al-Jami' lima Dhahaba min Kalam al-'Arab, Tahbir alMusyin fi al-Ta'bir bi al-Sin wa al-Syin, Syarh Qashidah; Bait Sa'ad, AlRaudh al-Masluf fima lahu Isman ila Uluf, al-Darar al-Mubatthathah fi alGarar al-Muthallathah, al-Muthallath al-Kabir, Anwa' al-Ghayth fi Asma alLaits, Asma al-Siraj fi Asma al-Nikah, Maqshud Dhawi al-Albab fi Ilm alI'rab, Raudhat al-Nazir fi Tarjamat al-Syaikh 'Abd al-Qadir, al-Mirqat alArfa'iyah fi Thabaqat al-Syafi'iyah, al-Mirqat al-Wafiyah fi Thabaqat alHanafiah, Nuzhat al-Adhhan fi Tarikh Ashbahan, al-Balghah fi Tarajim A'immat al-Nuhah wa al-Lughah, Syawariq al-Asrar fi Syarh Masyariq alAnwar al-Nabawiyah, Manh al-Bari fi Syarh Shahih al-Bukhari, al-Ahadis alDha'ifah, Tasyil Thariq al-Wushul ila al-Ahadis al-Zaidah, dan lainnya.

\section{c. Metode tafsir Tanwir al-Miqbas}

Adapun metode yang digunakan al-Fairuzabadi dalam menyusun kitab Tanwir al-Miqbas, sebagai berikut:

1) Sumber penafsiran

Sumber penafsiran yang digunakan oleh al-Fairuzabadi dalam penulisan kitab ini adalah menggunakan metode tafsir bi al-ma'tsur dengan pendapat Ibn 'Abbas sebagai 'sumber' rujukan penafsiran utama. Tampaknya,

\footnotetext{
${ }^{21}$ al-Dawusi, Thabaqat al-Mufassirin, 312.

${ }^{22}$ Al-Fairuzabadi, Tanwir al-Miqbas, vi.
} 
penulis ingin menyajikan semua penafsiran Ibn 'Abbas tanpa memandang kriteria sahih ataupun lemahnya. Pada setiap awal surat, al-Fairuzabadi mengawali penafsirannya dengan ungkapan: "Wa bi isnadih 'an Ibn 'Abbas." Dengan kata lain, penafsiran ayat-ayat yang disampaikannya di sandarkan kepada sanad yang telah tertera dalam muqaddimah tafsirnya, yaitu bermuara kepada Muhammad bin Marwan al-Suddi al-Shagir dari Muhammad bin alSaib al-Kalbi, dari Abu Shalih, dari Ibn 'Abbas. Jalur inilah yang dijadikan sandaran utama al-Fairuzabadi dalam menafsirkan ayat.

2) Cara penjelasan

Masa hidup al-Fairuzabadi berdekatan dengan penulis tafsir alJalalain, Jalaluddin al-Mahalli dan Jalaluddin al-Suyuthi. Sangat wajar kiranya apabila terdapat kemiripan dalam cara menafsirkan al-Qur'an, yakni pola yang sederhana dengan menampilkan makna kata atau padanan kata. Kesamaan itu tampaknya merupakan trend di masa itu untuk menghidangkan tafsir al-Qur'an yang sederhana, ringkas dan padat, yang merupakan ciri dari tafsir bayani, lawan dari muqarin.

3) Keluasan penjelasan

Cara penjelasan tafsir Tanwir al-Miqbas sangat global sehingga memudahkan pembaca sekaligus membiarkan pembaca mengembangkan sendiri seluas-luasnya pemahaman terhadap al-Qur'an. Berdasarkan ini, maka kitab tafsir ini masuk dalam kategori penjelasan ijmali.

4) Sasaran dan tertib ayat

Kitab tafsir ini hanya terdiri dari satu jilid dengan 600 halaman (Penerbit Dar al-Kutub al'Ilmiyah, Beirut). Namun sasaran dan tertib ayat yang ditafsirkan dimulai dari surat al-Fatihah dan berakhir dengan penafsiran surat al-Nas. Sehingga penafsiran yang dimulai dari awal hingga akhir merupakan ciri dari tafsir tahlili.

5) Kecenderungan alirannya

Penafsiran al-Fauruzabadi hanya menguraikan apa yang tersurat dari sisi kebahasaan setiap kalimat, dan tidak meneliti kandungan yang tersirat dari setiap ayat. Kenyataan ini mengindikasikan corak yang digunakan untuk menafsirkan al-Qur'an adalah lughawi. Tafsir kebahasaan muncul sebagai respon dari kebutuhan umat Islam khususnya non-Arab yang memeluk Islam serta kelemahan orang Arab sendiri di bidang bahasa, sehingga dirasakan perlu untuk menjelaskan kepada mereka tentang keistimewaan dan kedalaman arti kandungan al-Qur'an. 


\section{Tafsir al-Jalalain}

a. Biografi Jalaluddin al-Mahalli

Nama lengkap dari Jalaluddin al-Mahalli adalah Muhammad bin Ahmad bin Muhammad bin Ibrahim al-Mahalli al-Syafi'i. Lahir di Mesir pada tahun $791 \mathrm{H}$ dan wafat pada tahun 864 H/1505 M. Sedari kecil, kecerdasan dan keuletan Jalaluddin dalam menimba ilmu sudah tampak. Disebutkan bahwa Jalaluddin pernah berguru pada ulama-ulama besar seperti Mahmud alAqshirani, al-Burhan al-Baijuri, al-Syams al-Bisathi, dan al-'Ala' al-Bukhari. Ia menguasai berbagai macam disiplin ilmu agama, seperti fiqih, teologi, gramatika, logika dan beberapa disiplin ilmu yang lain. ${ }^{23}$

Karena kecerdasan dalam keilmuan, ia dijuluki dengan Jalaluddin. Sedangkan al-Mahalli merupakan penisbatan kepada tempat asalnya yakni alMahalla al-Kubra, suatu daerah di bagian barat kota Kairo. Diantara karyanya ialah Tafsir al-Jalalain yang kemudian ditamatkan oleh al-Suyuthi, Syarh Minhaj dan Syarh Jami' al-Jawami' dalam ushul fiqih. ${ }^{24}$

\section{b. Biografi al-Suyuthi}

Nama lengkap al-Suyuthi adalah 'Abdurrahman bin al-Kamal Abu Bakr bin Muhammad bin Sabiquddin bin al-Fakhr 'Usman bin Nadziruddin alHammam al-Khudhairi al-Suyuthi al-Thuluni al-Mishri al-Syafi'i. Ia dilahirkan pada tahun $849 \mathrm{H}$ dan wafat pada tahun $911 \mathrm{H}$. Ia termasuk seorang pakar tafsir, pakar fiqih madzhab Syafi' 'i, pakar hadis, sufi, dan teolog madzhab Asy'ariyah. Di antara guru-gurunya selain Ibn Hajar al-'Asqalani adalah Ahmad al-Syarmasahi, 'Umar al-Bulqini, Shalih bin 'Umar bin Ruslan alBulqini, Muhyiddin al-Khafaji, dan al-Qadhi Syarafuddin al-Munawi. Dalam menuntut ilmu, al-Suyuthi rihlah ke Fayyum, Mahallah, Dumyat, Syam, Hijaz, Yaman, India, dan Maroko. ${ }^{25}$

Al-Suyuthi besar di Kairo dalam keadaan yatim. Ayahnya meninggal dunia ketika ia berusia 5 tahun. Kemudian ketika berusia 40 tahun, ia mengisolir diri ke sebuah pulau kecil di tengah-tengah sungai Nil untuk menulis kitab. Sebagai seorang maestro handal dalam berbagai bidang keilmuan, al-Suyuthi telah melahirkan banyak karya-karya monumental, di antaranya: Tarjuman al-Qur'an yang kemudian diringkas menjadi Tafsir al-

${ }^{23}$ Muhammad Husein al-Dzahabi, al-Tafsir wa al-Mufassirun, Juz I, (Kairo: Maktabah Wahbah, 1998), 341.

${ }^{24}$ Al-Shiddiqi, Sejarah dan Pengantar Ilmu al-Qur'an, 242.

25 Muhammad Jalaluddin al-Suyuthi, al-Durr al-Mantsur fi al-Tafsir al-Ma'tsur, (Beirut: Dar al-Kutub al-'Ilmiyah, 1990), 3-4. 
Durr al-Mantsur fi al-Tafsir al-Ma'tsur, al-Takhbir fi 'Ulum al-Tafsir, Tanwir al-Hawalik Syarh 'ala Muwaththa' Malik, al-Jami' al-Kabir, Thabaqat alHuffaz, al-Hawi li al-Fatawi fi al-Fiqh wa 'Ulum al-Tafsir wa al-Hadis wa alUshul wa al-Nahwi wa al-I'rab wa Sa'ir al-Funun, al-Ashbah wa al-Nadza'ir fi al-Furu' al-Syafi'iyah, al-Radd 'ala man Akhlada ila al-Ardh wa Jahila anna al-Ijtihad fi Kull 'Ashr Fardh, Shawn al-Manthiq wa al-Kalam 'an Fann al-Manthiq wa al-Kalam, Husn al-Muhadharah fi Tarikh Misr wa al-Qahirah.

\section{c. Metode Tafsir al-Jalalain}

1) Sumber penafsiran

Tafsir Jalalain merupakan salah satu contoh tafsir yang menggunakan sumber akal dalam menafsirkan ayat-ayat al-Qur'an. Namun demikian, ada juga penjelasan-penjelasan yang menggunakan riwayat hadis dengan kapasitas yang sangat sedikit. Semua ayat dalam al-Qur'an dijelaskan secara sederhana oleh kedua Imamain Jalalain, sehingga sangat memudahkan dalam memahami makna al-Qur'an. Dengan demikian, penulis lebih cenderung untuk memasukkan Tafsir al-Jalalain ke dalam kategori tafsir bi al-ra'yi.

2) Cara penjelasan

Cara yang digunakan dalam Tafsir al-Jalalain untuk menjelaskan isi kandungan ayat al-Qur'an adalah menggunakan cara bayani. Selain itu, tafsir ini juga di jelaskan secara parsial dan tidak menjelaskan arti keseluruhan kata pada ayat-ayat al-Qur'an, namun hanya dijelaskan pada kata-kata tertentu yang memang memerlukan penjelasan.

3) Keluasan penjelasan

Dalam menafsiran ayat al-Qur'an, dua maestro mufassir ini tidak menggunakan metode yang detail dan panjang, namun menggunakan cara yang sederhana, ringkas, dan padat, sehingga mudah dimengerti oleh orang yang belum terlalu jauh mempelajari al-Qur'an. Dengan demikian, Tafsir Jalalain ini termasuk dalam jajaran tafsir ijmali.

4) Sasaran dan tertib ayat

Dilihat dari urutan atau tertib susunan ayat, Tafsir Jalalain termasuk tafsir yang menggunakan metode tahlili, yaitu menafsirkan ayat al-Qur'an sesuai dengan susunan mushaf dan menjelaskan setiap kata dalam suatu ayat yang dianggap perlu untuk dijelaskan dan melewatkan setiap kata yang sudah dianggap tidak memerlukan penjelasan.

5) Kecenderungan aliran Tafsir al-Jalalain 
Aliran tafsir Jalalain ini termasuk tafsir lughawi. Hal ini terbukti dari cara mufassir menjelaskan ayat dengan memperhatikan aspek kebahasaan, yakni berusaha menonjolkan analisis nahwu dan sharaf dari sisi susunan kalimat dan asal-usul kata yang ada dalam al-Qur'an.

\section{Kesimpulan}

Pembahasan dari tulisan ini menghasilkan temuan, sebagai berikut: pertama, pada abad kesembilan dan kesepuluh para mufassir dalam upaya menafsirkan al-Qur'an tidak lagi merasa cukup dengan hanya mengutip atau menghafal riwayat dari gerakan sahabat, tabi'in dan tabi'-tabi' in, tetapi mereka mulai berorientasi pada penafsiran al-Qur'an berdasarkan pada pendekatan ilmu bahasa dan penalaran ilmiah. Dengan kata lain, tafsir al-Qur'an pada periode ini tidak hanya mengandalkan kekuatan tafsir bi al-ma'tsur yang telah lama mereka warisi, tetapi juga berupaya keras mengembangkan tasir bi alra'yi dengan segala macam implikasinya.

Kedua, para mufassir pada abad kesembilan dan kesepuluh masa hidupnya saling berdekatan. Sangat wajar apabila terdapat kemiripan dalam menafsirkan ayat-ayat al-Qur'an, yakni pola sederhana dengan menampilkan makna kata maupun padanan kata. Kesamaan tersebut tampaknya merupakan trend di masa itu untuk menghidangkan tafsir al-Qur'an yang sederhana, ringkas dan padat. Secara umum, metodologi penafsiran pada abad ini antara lain; (1) sumber penafsirannya memadukan antara tafsir bi al-ma'tsur dan tafsir bi al-ra'yi; (2) cara penjelasannya menggunakan bayani; (3) keluasan penjelasannya mayoritas menggunakan metode ijmali; (4) sasaran dan tertib ayatnya memakai metode tahlili; dan (5) kecenderungan aliran dalam penafsirannya menggunakan aspek kebahasaan, yakni lughawi.

\section{Daftar Pustaka}

Al-Dawusi, Syamsuddin Muhammad bin 'Ali bin Ahmad. Thabaqat alMufassirin. Ttp: Maktabah Wahbah Abidin, 1992.

Al-Dzahabi, Muhammad Husain. al-Tafsir wa al-Mufassirun. Kairo: Dar alHadith, 2005.

al-Tafsir wa al-Mufassirun. Kairo: Maktabah Wahbah, 1998.

Al-Fairuzabadi, Abdullah Ibn 'Abbas Muhammad. Tanwir al-Miqbas min Tafsir Ibn 'Abbas. Amman: Royal Alul Bait, 2007. 
Al-Jundi, Farid 'Abdul 'Aziz. Mu'jam al-Buldan. Beirut: Dar al-Kutub al'Ilmiyyah, 1990.

Al-Shiddiqi, Muhammad Hasbi. Sejarah dan Pengantar Ilmu al-Qur'an dan Tafsir. Semarang: Pustaka Rizki Putra, 2012.

Al-Suyuthi, Muhammad Jalaluddin. al-Itqan fi 'Ulum al-Qur'an. Kairo: Dar al-Hadits, 2004.

----------. al-Durr al-Mantsur fi al-Tafsir al-Ma'tsur. Beirut: Dar al-Kutub al-'Ilmiyah, 1990.

Al-Zarqani, Muhammad 'Abdul 'Adzim. Manahil al-'Irfan fi 'Ulum alQur'an. Beirut: Dar al-Kutub al-'Arabi, 1995.

Falahudin. Dkk. Kuliah Kemuhammadiyahan. Mataram: LP2I UM. Mataram, 2015.

Goldziher, Ignaz. Madzhab Tafsir. Terj. Alaika Salamullah dkk. Jogjakarta: Elsaq Press, 2010.

Izzan, Ahmad. Metodologi Ilmu Tafsir. Bandung: Tafakur, 2009.

Mustaqim, Abdul. Aliran-aliran Tafsir. Yogyakarta: Kreasi Wacana, 2005.

Shihab, M Quraish. Membaca Sirah Nabi Muhammad Saw Dalam Sorotan alQur'an dan Hadits-Hadits Shahih. Jakarta: Lentera hati, 2011.

Yatim, Badri. Sejarah Kebudayaan Islam. Jakarta: PT Rajawali Press, 2014.

Zulfikar, Eko. Makna Ulu al-Albab Dalam al-Qur'an: Analisis Semantik Toshihiko Izutsu, dalam Jurnal Theologia, Vol 29, No 1, Juni 2018. 